\title{
Assembly of the Armorica Microplate: A Strike-Slip Terrane Delivery? Evidence from U-Pb Ages of Detrital Zircons
}

\author{
Javier Fernández-Suárez, Gabriel Gutiérrez Alonso, ${ }^{1}$ Richard Cox, ${ }^{2}$ \\ and George A. Jenner ${ }^{2}$ \\ Departamento de Petrología y Geoquímica, Universidad Complutense, 28040 Madrid, Spain \\ (e-mail: jfsuarez@eucmos.sim.ucm.es)
}

\begin{abstract}
A B S T R A C T
Detrital zircons separated from the Ordovician Armorican quartzite in the foreland of the Variscan belt of Iberia were dated by laser ablation inductively coupled plasma mass spectrometry. The age groups found correspond to Proterozoic and Archean crust formation events. The Proterozoic events reflected by zircon ages are Avalonian-Cadomian-PanAfrican (550-800 Ma), Grenvillean-Sunsas (900-1300 Ma), and Eburnian-Transamazonian-Icartian (1800-2200 Ma). Archean zircon ages are comprised between 2500 and $2800 \mathrm{Ma}$ (Central-Amazonian-Liberian events). The presence of Mesoproterozoic (Grenvillean) zircons in the Armorican quartzite, which was deposited in a shallow platform bordering the NW African craton (north Gondwana margin), suggests that the NW Iberian terrane drifted from the South American margin, where it was located during the Neoproterozoic, toward Africa. The drift of the Iberian block, likely achieved via transform faults, was arrested by its docking and amalgamation with the peri-NW African Neoproterozoic terranes, resulting in the birth of the Paleozoic Armorica Terrane Assemblage.
\end{abstract}

\section{Introduction}

The history of the earth's crust can be regarded as a continuous process of dispersal and accretion of crustal fragments and concomitant creation, destruction, and recycling of crustal material. Most orogenic belts result from the tectonic amalgamation of terranes or lithospheric fragments of assorted provenance, which often contain information relating to their original setting and to subsequent events of dispersal and/or accretion. Therefore, geological investigations of orogenic belts include identification of individual crustal components and deduction of the tectonic evolution prior to and during their accretion.

The late Paleozoic Variscan collision belt in western Europe involves a number of crustal blocks with Precambrian basement that originally formed part of the Neoproterozoic peri-Gondwanan assemblage of terranes that made up the CadomianAvalonian arc (e.g., Nance and Murphy 1996; Un-

\footnotetext{
Manuscript received May 15, 2001; accepted November 6, 2001.

${ }^{1}$ Departamento de Geología, Universidad de Salamanca, 33708 Salamanca, Spain; e-mail: gabi@gugu.usal.es.

${ }^{2}$ Department of Earth Sciences, Memorial University of Newfoundland, St. John's, Newfoundland A1B 3X5, Canada.
}

rug 1997). These crustal blocks were developed on ancient cratonic basement (including interior collisional orogens of supercontinent assembly), whose nature varied along the northern Gondwanan margin. Combined $\mathrm{U}-\mathrm{Pb}$ and $\mathrm{Nd}$ isotopic studies have allowed the distinction of two main signatures in these terranes: terranes with a NW African craton affinity and terranes with South America craton affinities. The main difference between the two terrane types is the presence of Mesoproterozoic zircons (ca. 1600-1000 Ma) in the latter, often coupled with higher whole-rock $\epsilon_{\mathrm{Nd}}$ values (e.g., Kröner et al. 1988; Mueller et al. 1994; Nance and Murphy 1996; Keppie et al. 1998; Miller et al. 1998; Fernández-Suárez et al. 1999, 2000; Friedl et al. 2000; Hegner and Kröner 2000; Linnemann et al. 2000). These terranes, formed as a result of Neoproterozoic subduction and arc construction along the northern Gondwanan margin, were dispersed as subduction was replaced by the transform/extensional activity that caused the breakup of the supercontinent margins and the birth of the Rheic Ocean (Murphy and Nance 1989; Murphy et al. 2000). Paleomagnetic, faunal, and geological evidence indicate that this ocean sepa- 
rated two terrane assemblages formed by dismembered fragments of the Avalonian-Cadomian belt: (1) Avalonia, formed by present-day Nova Scotia, Avalon Peninsula of Newfoundland, coastal New England, New Brunswick, and Carolina-Swanee in North America and the southern part of the British Isles, the Ardennes, and the Rheno-Hercynian zone of Germany in western Europe, and (2) Armorica, formed by the French Armorican Massif, Iberia, and the Saxothuringian and Moldanubian zones of central Europe. Western European terranes with Cadomian-Avalonian basement are presently contained within the Variscan and Alpine fold belts.

This contribution attempts to constrain the early Paleozoic paleogeographic and paleotectonic scenarios along the periphery of Gondwana based on the study of age populations of detrital zircons in the Ordovician Armorican quartzite of NW Iberia. Because of its age, lateral extent, stratigraphic position, and use as a marker, a better understanding of the Armorican quartzite in western Europe is a key to unraveling the complex terrane interactions along the Gondwanan margin. In turn, a better understanding of the evolution of the northern Gondwanan margin is essential to Neoproterozoic and early Paleozoic terrane reconstructions.

\section{Geologic Setting: The Armorican Quartzite}

Paleogeographic reconstructions of southern Europe and northern Africa for early Paleozoic times (e.g., McKerrow and Scotese 1990; Paris and Robardet 1990; Robardet 2000) agree on the presence of an extensive shallow continental platform close to the South Pole and bordering the African section of the Gondwana supercontinent, where the Armorican quartzite was deposited during the Middle Ordovician (after ca. 465 Ma; Bonjour et al. 1988). In present-day exposures of Gondwanan terranes, the Armorican quartzite occurs in Iberia, Armorican and Bohemian Massifs, Corsica, Turkey, and several realms of North and West Africa. In western Europe, the Armorican quartzite lies unconformably on top of Precambrian and Cambrian rocks (Sardic unconformity) (Aramburu and García Ramos 1988; Brun et al. 1991) and was deposited after Cambrian-Early Ordovician magmatic activity in NW Iberia ("Ollo de Sapo" belt and related rocks; Valverde-Vaquero and Dunning 2000) and in Armorica (Le Corre 1994).

A type locality for these quartzites in NW Iberia is the core of the Viyazón-Reigada syncline (fig. 1). The Barrios Quartzite Formation (local name for the Armorican quartzite in the Cantabrian Zone of NW Iberia) is composed of extremely pure, white quartzites. The unit is interpreted to have been deposited in a braid-plain delta environment with marine influence. The paleocurrent data and facies distribution indicate that transport occurred from east to west in present-day coordinates, i.e., from the core of the Ibero-Armorican arc (fig. 1) toward a deeper marine environment. Detailed sedimentological data and stratigraphic correlations are given in Aramburu and García Ramos (1993).

\section{Analytical Method for U-Pb Dating}

$\mathrm{U}-\mathrm{Pb}$ dating of individual zircon grains was made using 266-nm laser ablation inductively coupled plasma mass spectrometry (ICP-MS) at Memorial University of Newfoundland. Zircons were separated using conventional heavy mineral separation techniques and were selected (by handpicking) to represent all types found in the sample in terms of size, shape, and other salient morphological features. Zircons were subsequently set in synthetic resin mounts and were polished. Cathodoluminescence (CL) and back-scattered electron (BSE) imaging was performed to ensure that analyses did not straddle different domains, as indicated by the BSE or CL structure. Spot analyses $<50 \mu \mathrm{m}$ in diameter were always performed on homogeneous $\mathrm{CL}$ and BSE domains to ensure that measured U$\mathrm{Pb}$ ratios did not represent mixtures of two or more age components. Discordant analyses were discarded when matching concordant $\mathrm{U}-\mathrm{Pb}$ ages were not obtained. Analytical facilities are those described in Jackson et al. (1997) and FernándezSuárez et al. (2000), but the analytical method differs from the above in that a solution containing known amounts of $\mathrm{Tl}$ and ${ }^{235} \mathrm{U}$ was used for calibration instead of external calibration to a zircon standard. The solution is nebulized in the sample chamber simultaneous with ablation. A description of the overall methodology is given in Horn et al. (2000).

\section{U-Pb Ages of Detrital Zircons}

A total of 90 analyses were performed on single grains, and the results are shown in the concordia diagrams of figure 2 and the histogram of figure 3. The concordia diagrams report only analyses $<10 \%$ discordant, whereas the histogram of figure 3 includes 43 analyses with discordance between 10\% and $25 \%$.

Zircons can be divided into three main types (fig. 4 ) on the basis of morphology and internal zoning. Type 1 zircons, the most abundant (inset in fig. 3), are clear, elongated subfaceted crystals. They can 


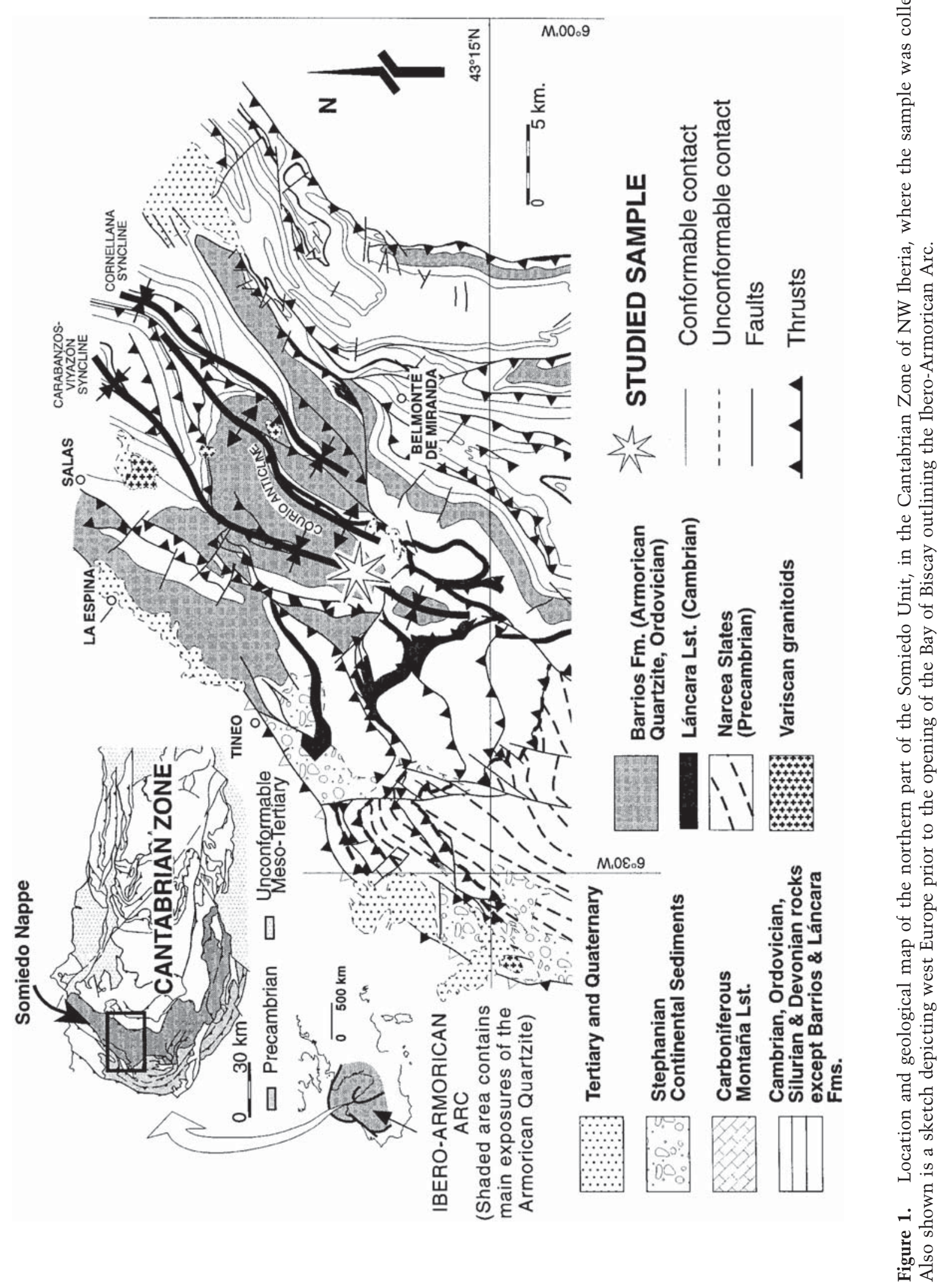



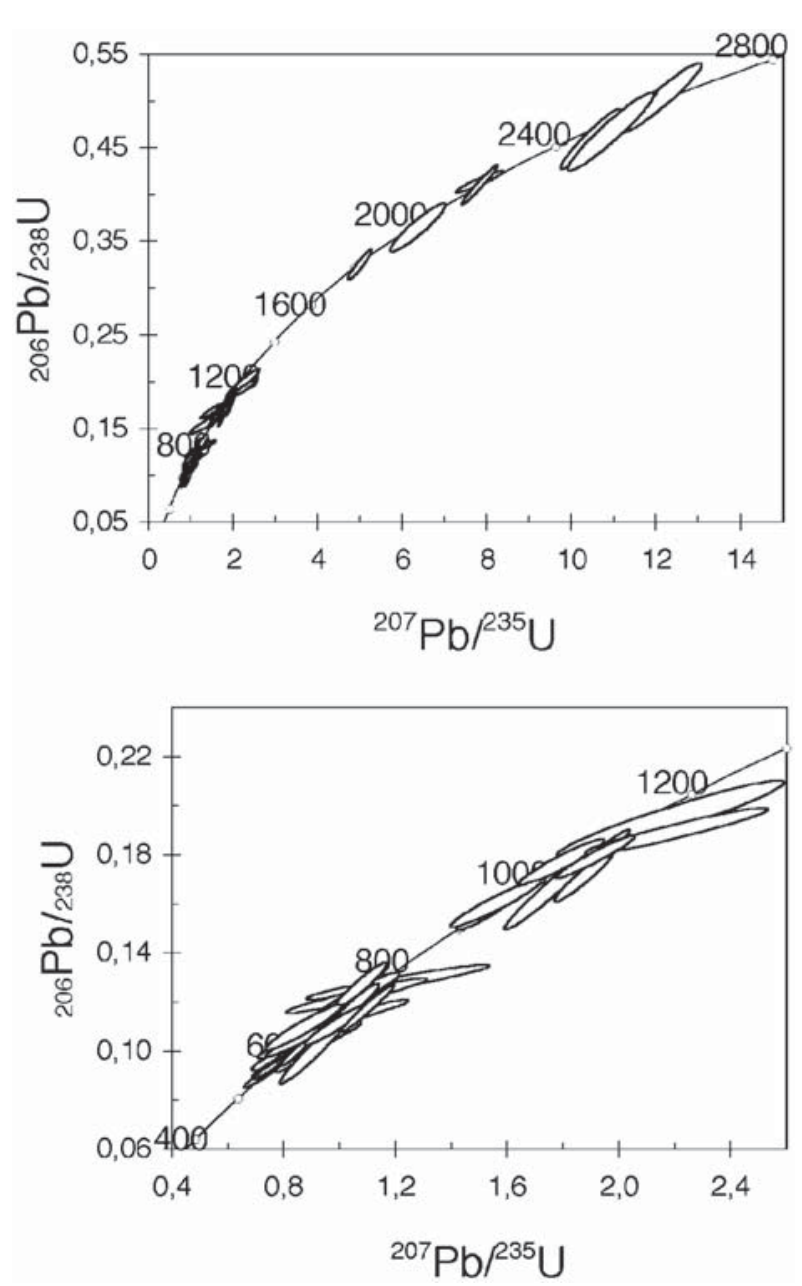

Figure 2. Concordia plots of U-Pb analytical data. Ellipses represent $2 \sigma$ uncertainties. The lower plot is an enlargement of the youngest section of the concordia represented in the upper plot.

be further subdivided into $1 \mathrm{a}, 1 \mathrm{~b}$, and $1 \mathrm{c}$ subcategories with increasing degree of roundness. Internally, type 1a grains display simple oscillatory zoning, whereas types $1 \mathrm{~b}$ and 1c commonly display inherited cores. Type 2 zircons are larger, subhedral, and more strongly colored. These grains are often fragmented. Internal structures are more complex with grains displaying both oscillatory zones (type $2 \mathrm{a})$ and complex zonation, indicative of crystal resorption (type 2b). The sample also contained rounded, red-brown-colored crystals (type 3), which are less abundant.

The U-Pb ages indicate a predominance of zircons in the age range $550-800 \mathrm{Ma}$ (type $1 \mathrm{a}$, rims of $1 \mathrm{~b}$ and $1 \mathrm{c}$, and type 2), which corresponds to the Cadomian-Avalonian-Pan-African events (ca. 32\% of analyses; figs. 2, 3). The second group in abundance consists of Mesoproterozoic (Grenvillean) zircons in the age range 900-1300 Ma (ca. 26\% of analyses and present in all morphological types; figs. 2, 3), which corresponds to the Early Brasiliano, Sunsas, and Oaxacan events in Central and South America (Hartmann 2001; Keppie et al. 2001). No concordant ages were found in the interval ca. $1300-1800 \mathrm{Ma} \cdot{ }^{207} \mathrm{~Pb} /{ }^{206} \mathrm{~Pb}$ ages from six discordant grains occur in that range (fig. 3), which corresponds to Mid-Proterozoic events in the South American craton (Rondonian and Rio Negro).

Older zircons have Paleoproterozoic ages (1800$2300 \mathrm{Ma})$ (12 zircons, ca. 13\%; fig. 2, top; fig. 3) that correspond to events in NW Africa (Eburnian), Amazonian Craton (Trans-Amazonian), and western Europe (Icartian) and Archean ages (2.5-2.8 Ga; fig. 2, top; fig. 3) corresponding to the Liberian (Africa) and Central-Amazonian (South America) events (16 analyses, ca. 18\%). Paleoproterozoic and Archean zircons were found as cores in types 1 and 2 and in type 3. These Archean zircons are equivalent in age to felsic and mafic granulite boulders collected in the submarine environment off the northern coast of Spain (Guerrot et al. 1989). The oldest zircon (type 3; fig. 3) found in this study yielded a subconcordant age of $3.09 \mathrm{Ga}$, which may correspond to the Leonian event in the NW African craton.

These age groups are similar to those found in Neoproterozoic and Cambrian rocks of NW Iberia and other areas of the SW European Variscides (Gebauer et al. 1989; Fernández-Suárez et al. 2000;

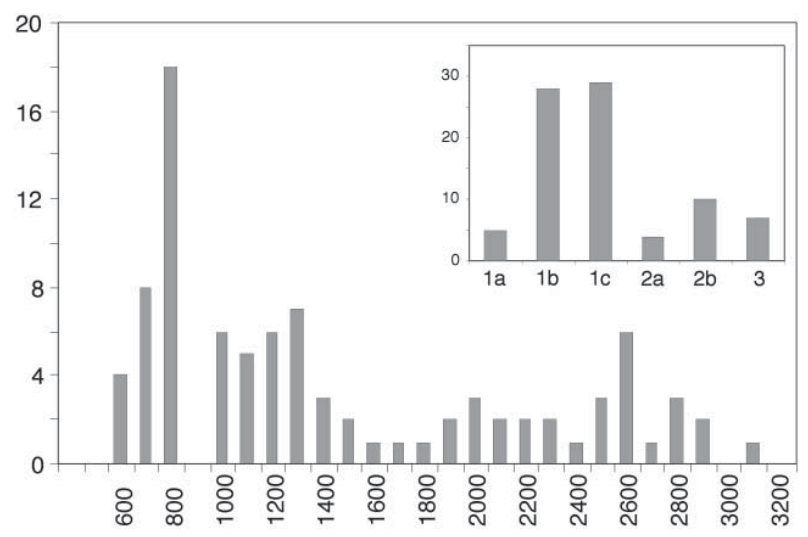

Figure 3. Histogram of U-Pb ages. The plot has been constructed using the best age estimate and error for each analysis (concordia ages and errors as defined by Ludwig 1998 for concordant analyses and ${ }^{207} \mathrm{~Pb} /{ }^{206} \mathrm{~Pb}$ ages for discordant analyses). Inset represents the relative abundance of morphological types. 


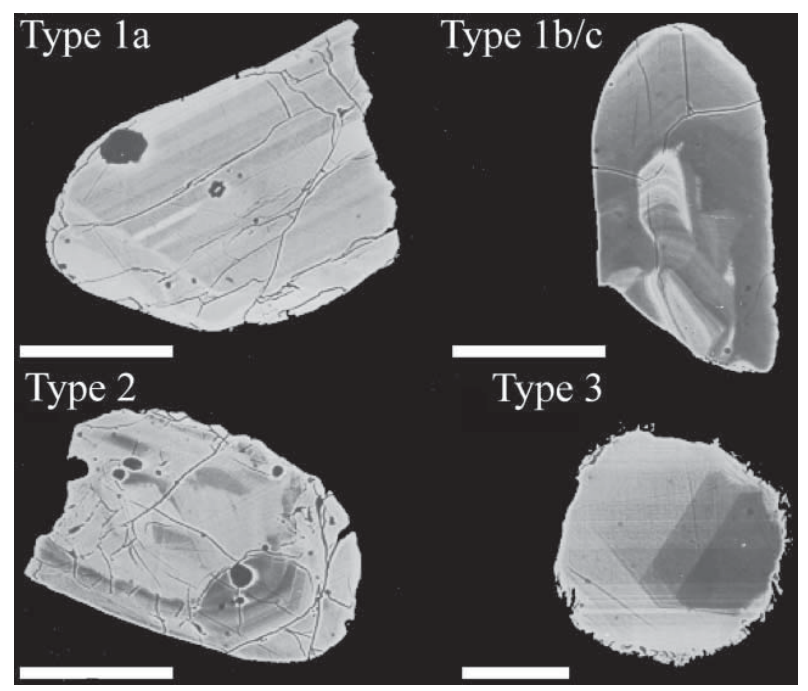

Figure 4. Back-scattered electron images of zircons from the Armorican Quartzite. Scale bars are $100 \mu \mathrm{m}$.

Friedl et al. 2000; Hegner and Kröner 2000; Linnemann et al. 2000) and are roughly coincident with those reported from West Avalonia (compilation in Nance and Murphy 1996; Keppie et al. 1998). It is also important to note that the relative amount of Paleoproterozoic and Archean zircons is significantly higher in the Armorican quartzite /ca. $25 \%-30 \%$ ) than in Neoproterozoic and Early Cambrian greywackes and arkoses from neighboring areas of NW Iberia (10\%-15\%; Fernández-Suárez et al. 2000).

\section{Discussion}

This study shows that the Ordovician Armorican quartzite contains zircons of varied ages (from Archean to uppermost Neoproterozoic). This range attests to a complex history of recycling, recording events related to the Cadomian-Avalonian-PanAfrican orogeny in the northern margin of Gondwana and cratonic provinces involved in it.

Recent studies (Fernández-Suárez et al. 2000; Friedl et al. 2000; Hegner and Kröner 2000; Linnemann et al. 2000) provide evidence that indicates that some of the western European Variscan units (NW Iberia, Moravo-Silesian unit of the Bohemian Massif, West Sudetes, and Erzgebirge) previously considered to have an African affinity appear to have been situated along the periphery of the South American craton during Neoproterozoic times (fig. $5 A$ ). However, there is faunal, paleomagnetic, and geologic evidence indicating that in the early $\mathrm{Pa}$ - leozoic these terranes were located on the periphery of NW Africa with other terranes that had presumably occupied that position since the Neoproterozoic (Cadomia, SW Iberia, Saxothuringian, and Moldanubian zones of central Europe), forming the so-called Armorica realm (or Armorican Terrane Assemblage) (Tait et al. 1997 and references therein; Linnemann et al. 2000; Robardet 2000).

The absence of Mesoproterozoic events in the NW African craton implies that the source for zircons in that age range in the Armorican quartzite must have been tectonically transferred from a peri-South American realm. The actual rocks whose erosion yielded Mesoproterozoic zircons must belong to the Neoproterozoic-Cambrian Iberia (and related terranes) and its pre-Neoproterozoic basement, which contain zircon populations with South American signatures (Fernández-Suárez et al. 1999, 2000). To reconcile the presence of abundant Grenvillean zircons in the Armorican quartzite with its deposition in a NW African realm, it is necessary to consider a drift of PrecambrianCambrian NW Iberia (including pre-Neoproterozoic basement) toward a NW African position.

We suggest that this drift might have occurred by means of strike-slip activity and concomitant terrane dispersal initiated along transform faults during the late Neoproterozoic in a tectonic scenario akin to that proposed by van Staal et al. (1996) and culminated in a collage of microplates that were assembled by the Cambrian-Early Ordovician (fig. 5). Africa-ward migration of NW Iberia (and presumably other west European peri-South American units) along the transform fault system ended with the docking of these drifting blocks against the European terranes that had occupied a peri-NW African location since the Neoproterozoic. This docking would represent the assembly (or birth) of the Armorican plate (fig. 5B) (or Armorican Terrane Collage as referred to by some authors; e.g., Linnemann et al. 2000 and references therein) and explains why this unit is constituted by terranes with a NW African affinity and terranes with a South American affinity.

The Armorican quartzite was deposited after the amalgamation of these blocks as indicated by the age populations of detrital zircons, providing a minimum age constraint (ca. $460 \mathrm{Ma}$ ) for the docking between NW Africa- and South America-derived blocks. The precise tectonic nature of the docking cannot be reliably ascertained at present, owing to the effects of the Variscan collision. This crustal ensemble, formed by microterranes tectonically placed together in the early Paleozoic (CambrianEarly Ordovician), evolved as a single block 


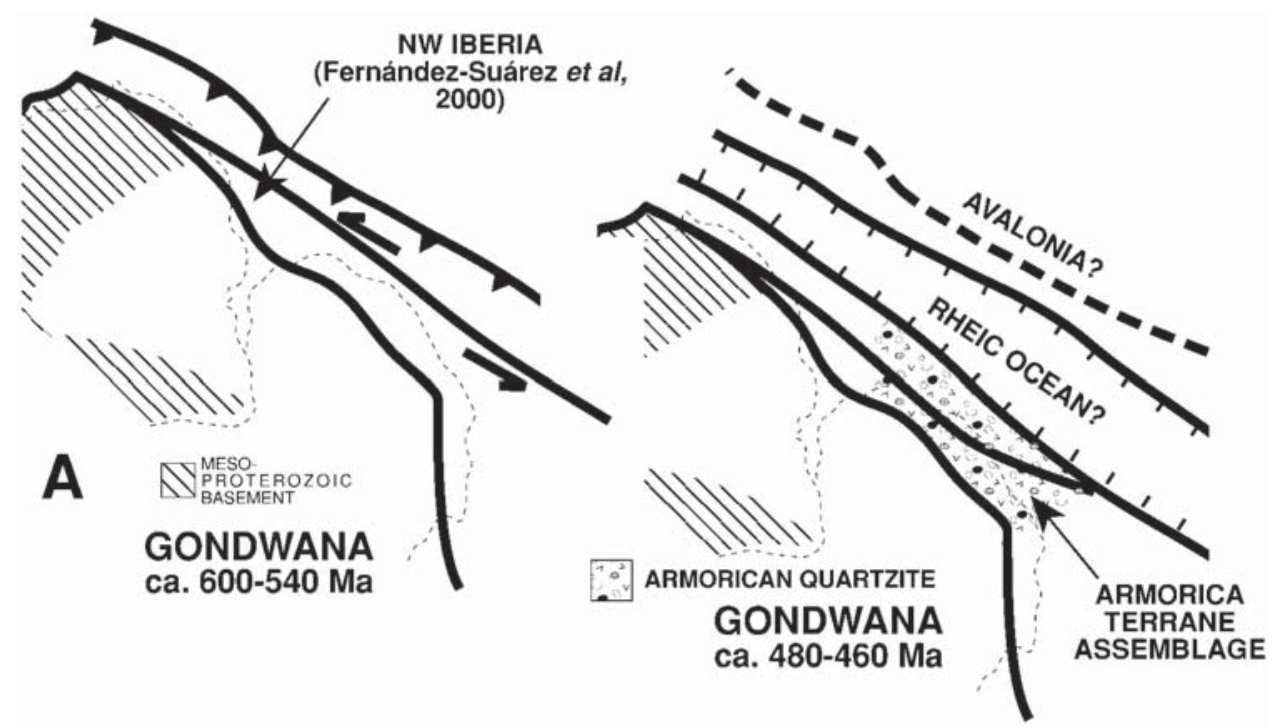

Figure 5. Illustration of the original position of NW Iberia in the Cadomian-Avalonian Arc $(A)$ and its migration to a peri-NW African location prior to the deposition of the Armorican quartzite.

throughout the rest of the Paleozoic (e.g., Tait et al. 1997). The tectonic scenario proposed herein implies a change from subduction and transform activity parallel to the margin to a passive margin environment where the Armorican quartzite was deposited (fig. 5). Although the precise nature and causes for these processes cannot be ascertained on the basis of available data, we suggest that oblique subduction along the margin and diachronous arrest of subduction might have favored the conditions for the onset of transform activity (FernándezSuárez et al. 2000). After amalgamation of crustal fragments via wrench faults, a change in the overall tectonic regime caused by the onset of extension roughly perpendicular or at high angle to the margin gave birth to the Armorican platform, the birth of the Rheic Ocean, and the migration of Avalonia away from the Gondwanan margin (fig. 5B; Fernández-Suárez et al. 2000).

Another point of importance is the seeming abundance of Paleoproterozoic and Archean zircons in the quartzite, compared to Neoproterozoic and Cambrian rocks of the same area (Fernández-Suárez et al. 2000), which is in agreement with the strongly negative $\epsilon_{\mathrm{Nd}}$ values in rocks belonging to this formation (at $470 \mathrm{Ma}, \epsilon_{\mathrm{Nd}}<-11$; Nägler et al. 1995). This suggests that the Armorican quartzite received detritus from the newly assembled Armorican realm and a significant input from the NW African craton inland. The abundance of Avalonian-Cadomian-Pan-African zircons reveals that these terranes, formed by Neoproterozoic subduction and arc construction in the margin of Gondwana, were eroded from the late Neoproterozoic (Fernández-Suárez et al. 2000) until at least the Ordovician. However, part of the dominant 550-800Ma population could also have its provenance in the Trans-Saharan or other interior orogens of the African craton (e.g., Unrug 1997).

Another issue raised by the zircon ages in the Armorican quartzite is the seeming absence or paucity (if we assume the discordant ages in that interval to be meaningful) of ca. 1300-1800-Ma zircons in NW Iberia compared to other European terranes with South American signatures /cf. Fernández-Suárez et al. 2000; Friedl et al. 2000; Linnemann et al. 2000). Zircons of that age are also absent in Neoproterozoic and Cambrian rocks of NW Iberia, with the exception of a few highly discordant analyses (Fernández-Suárez et al. 2000). Understanding this feature might yield important paleogeographic information and would require the linkage of NW Iberia with a realm in which Grenvillean zircons (broadly 900-1300 Ma) were present and accessible but did not yield/bear older Mesoproterozoic zircons such as those found in the Rondonian and Rio Negro terranes of South America. To our knowledge, only the Carolina-Suwanee terrane of eastern North America contains an equivalent zircon age spread (Mueller et al. 1994; Miller et al. 1998) and was situated in a position that could have been close to Iberia in a segment of the Gond- 
wana margin that did not receive detritus from rocks recording the 1300-1800-Ma events in South America (see Dalziel 1997).

Another salient feature of the Armorican quartzite is the absence of zircons in the age range ca. 520-480 Ma. Zircons in this age cluster are found in volcanic, volcanosedimentary, and plutonic rocks formed in relation to the extensional tectonics and lithospheric thinning that caused the breakup of the Gondwana margin (Murphy et al. 1996; Fernández-Suárez et al. 1999). In NW Iberia, these rocks are known as "Ollo de Sapo Complex" and are widely exposed west of the Cantabrian Zone where the sample was collected. This fact places a paleogeographic limit to the extent of that magmatic event toward the core of the IberoArmorican Arc, which in terms of Ordovician Gondwana margin paleogeography, implies the absence of this extension-related event toward the continent.

\section{Conclusions}

NW Iberia was amalgamated, together with other South America-derived crustal blocks, to their peri-NW African counterparts in Cambrian-Early Ordovician times. It is proposed that this amalgamation took place via large scale wrench/transform faulting roughly parallel to the extended margin of Gondwana. After amalgamation, the Armorican quartzite was deposited on a Gondwana peripheral platform postdating the strike-slip transport and the birth of Armorica. After this, the crustal ensemble known as "Armorica" evolved as a single realm throughout the Paleozoic until it was finally involved in the Variscan Laurentia-Gondwana collision. A preliminary note of caution is introduced regarding the possible absence of ca. 1300-1800-Ma zircons in NW Iberia, which could single out this terrane in relation to other European Gondwanan terranes with South American signatures. The paleogeographic implications must be investigated as they may offer new constraints on the geography of the northern Gondwanan margin during the Neoproterozoic-early Paleozoic.

\section{A C K N O W LED G M ENTS}

This study was funded through projects DGCYCT PB96-1452-C03-02 and BTE2000-1490-C02-01. J. Fernández-Suárez wishes to acknowledge a Contrato de Reincorporación from the Spanish Ministry of Education. Encouraging and constructive reviews by J. D. Gleason and J. B. Murphy are kindly acknowledged.

\section{REFEREN C E S C I T E D}

Aramburu, C., and García Ramos, J. C. 1988. Presencia de la discontinuidad Sárdica en la Zona Cantábrica. Geogaceta 5:11-13.

1993. La sedimentación Cambro-Ordovícica en la Zona Cantábrica (NO de España). Trab. Geol. 19: 45-73.

Bonjour, J. L.; Peucat, J. J.; Chauvel, J. J.; Paris, F.; and Cornichet, J. 1988. U-Pb zircon dating of the early Paleozoic (Arenigian) transgression in western Brittany (France): a new constraint for the Lower Paleozoic timescale. Chem. Geol. 72:329-336.

Brun, J. P.; Ballard, J. F.; and Le Corre, C. 1991. Identification of Ordovician block tilting in the Hercynian fold belt of central Brittany (France): field evidence and computer models. J. Struct. Geol. 13:419-429.

Dalziel, I. W. D. 1997. Neoproterozoic-Paleozoic geography and tectonics: review, hypothesis, environmental speculation. Geol. Soc. Am. Bull. 109:16-42.

Fernández-Suárez, J.; Gutiérrez Alonso, G.; Jenner, G. A.; and Tubrett, M. N. 1999. Crustal sources in Lower Palaeozoic rocks from NW Iberia: insights from laser ablation U-Pb ages of detrital zircons. J. Geol. Soc. Lond. Spec. Publ. 156:1065-1068.

. 2000. New ideas on the Proterozoic-early Paleozoic evolution of NW Iberia: insights from U-Pb detrital zircon ages. Precambrian Res. 102:185-206.
Friedl, G.; Finger, F.; McNaughton, N. J.; and Fletcher, I. R. 2000. Deducing the ancestry of terranes: SHRIMP evidence for South America-derived Gondwana fragments in central Europe. Geology 28:1035-1038.

Gebauer, D.; Williams, I. S.; Compston, W.; and Grünenfelder, M. 1989. The development of the central European continental crust since the Early Archean based on conventional and ion-microprobe dating of up to 4.84 b.y. old detrital zircons. Tectonophysics 157:81-96.

Guerrot, C.; Peucat, J. J.; Capdevila, R.; and Dosso, L. 1989. Archean protoliths within Early Proterozoic granulitic crust of the west European Hercynian belt: possible relics of the west African craton. Geology 17: 241-244.

Hartmann, L. A. 2001. U-Pb zircon SHRIMP geochronology of orogenic cycles and supercontinents in the southern Brazilian shield. EUG XI, Abstr., p. 597.

Hegner, E., and Kröner, A. 2000. Review of Nd isotopic data and xenocrystic and detrital zircon ages from the pre-Variscan basement in the eastern Bohemian Massif: speculations on palinspastic reconstructions. In Franke, W.; Haak, V.; Oncken, O.; and Tanner, D., eds. Orogenic processes: quantification and modelling in the Variscan belt. Geol. Soc. Spec. Publ. 179:167-175. Horn, I.; Rudnick, R. L.; and McDonough, W. F. 2000. 
Precise elemental and isotope ratio determination by simultaneous solution nebulization and laser ablation ICP-MS: application to U-Pb geochronology. Chem. Geol. 167:405-425.

Jackson, S. E.; Longerich, H. P.; Horn, I.; Dunning, G. 1997. The application of laser ablation microprobe (LAM) ICP-MS to in situ U-Pb zircon geochronology. Proc. Goldschmidt Conf., Strasbourg, p. 283-284.

Keppie, J. D.; Davis, D. W.; and Krogh, T. E. 1998. U-Pb geochronological constraints on Precambrian stratified units in the Avalon Composite Terrane of Nova Scotia, Canada: tectonic implications. Can. J. Earth Sci. 35:222-236.

Keppie, J. D.; Dostal, J.; Ortega-Gutierrez, F.; and Lopez, R. 2001. A Grenvillian arc on the margin of Amazonia: evidence from the southern Oaxacan complex, southern Mexico. Precambrian Res. 112:165-181.

Kröner, A.; Wendt, I.; Compston, W.; Todt, W.; Fiala, J.; Vankova, V.; and Vanek, J. 1988. U-Pb zircon and Sm$\mathrm{Nd}$ model ages of high grade Moldanubian metasediments, Bohemian Massif, Czechoslovakia. Contrib. Mineral. Petrol. 99:257-266.

Le Corre, C. 1994. Early tectonic events (Ordovician). In Keppie, J. D., ed. Pre-Mesozoic geology in France and related areas. Berlin, Springer, p. 179-182.

Linnemann, U.; Gehmlich, M.; Tichomirowa, M. H.; Buschmann, B.; Nasdala, L.; Jonas, P.; Lützner, H.; and Bombach, K. 2000. From Cadomian subduction to early Paleozoic rifting: the evolution of SaxoThuringia in the margin of Gondwana in the light of single zircon geochronology and basin development (Central European Variscides, Germany). In Franke, W.; Haak, V.; Oncken, O.; and Tanner, D., eds. Orogenic processes-quantification and modeling in the Variscan belt of central Europe. Geol. Soc. Lond. Spec. Publ. 179:131-153.

Ludwig, K. R. 1998. On the treatment of concordant uranium-lead ages. Geochim. Cosmochim. Acta 62: 665-676.

McKerrow, W. S., and Scotese, C. R., eds. 1990. Palaeozoic palaeogeography and biogeography. Geol. Soc. Am. Mem. 12, 435 p.

Miller, C. F.; Hatcher, R. D.; Harrison, T. M.; Coath C. D.; and Gorisch, E. B. 1998. Cryptic crustal events elucidated through zone imaging and ion microprobe studies of zircon, southern Appalachian Blue Ridge, North Carolina-Georgia. Geology 26:419-422.

Mueller, P. A.; Heatherington, A. L.; Wooden, J. L.; Schuster, R. D.; Nutman, A. P.; and Williams, I. S. 1994. Precambrian zircons from the Florida basement: a Gondwanan connection. Geology 22:119-122.

Murphy, J. B.; Keppie, J. D.; Dostal, J.; and Cousens, B.
L. 1996. Repeated late Neoproterozoic-Silurian lower crustal melting beneath the Antigonish Highlands, Nova Scotia: Nd isotopic evidence and tectonic interpretations. In Nance, R. D., and Thompson, M. D., eds. Avalonian and related peri-Gondwanan terranes of the circum-North Atlantic. Geol. Soc. Am. Spec. Pap. 304:109-120.

Murphy, J. B., and Nance, R. D. 1989. Model for the evolution of the Avalonian-Cadomian belt. Geology 17: 735-738.

Murphy, J. B.; Strachan, R. A.; Nance, R. D.; Parker, K. D.; and Fowler M. B. 2000. Proto-Avalonia: a 1.2-1.0 Ga tectonothermal event and constraints for the evolution of Rodinia. Geology 28:1071-1074.

Nägler, T. F.; Schäfer, H. J.; and Gebauer, D. 1995. Evolution of the western European continental crust: implications from $\mathrm{Nd}$ and $\mathrm{Pb}$ isotopes in Iberian sediments. Chem. Geol. (Isotope Geoscience Section) 121: 345-347.

Nance, R. D., and Murphy, J. B. 1996. Basement isotopic signatures and Neoproterozoic paleogeography of Avalonian-Cadomian and related terranes in the Circum-North Atlantic. In Nance, R. D., and Thompson, M. D., eds. Avalonian and related peri-Gondwanan terranes of the circum-North Atlantic. Geol. Soc. Am. Spec. Pap. 304:109-120.

Paris, F., and Robardet, M. 1990. Early Palaeozoic palaeobiogeography of the Variscan regions. Tectonophysics 177:193-213.

Robardet, M. 2000. An alternative approach to consider the Variscan belt in SW Europe: the preorogenic paleogeographical constraints. In Variscan-Appalachian dynamics: the building of the Upper Paleozoic basement. Basement Tectonics 15, p. 23-26.

Tait, J. A.; Bachtadse, V.; Franke, W.; and Soffel, H. C. 1997. Geodynamic evolution of the European Variscan fold belt: paleomagnetic and geological constraints. Geol. Rundsch. 86:585-598.

Unrug, R. 1997. Rodinia to Gondwana: the geodynamic map of Gondwana supercontinent assembly. GSA Today $7: 1-7$

Valverde-Vaquero, P., and Dunning, G. R. 2000. New U$\mathrm{Pb}$ ages for Early Ordovician magmatism in central Spain. J. Geol. Soc. 157:15-26.

van Staal, C. R.; Sullivan, R. W.; and Whalen, J. B. 1996. Provenance and tectonic history of the Gander Zone in the Caledonian/Appalachian orogen: implications for the origin and assembly of Avalon. In Nance, R. D., and Thompson, M. D., eds. Avalonian and related peri-Gondwanan terranes of the circum-North Atlantic. Geol. Soc. Am. Spec. Pap. 304:347-367. 
Copyright $@ 2002$ EBSCO Publishing 